Article

\title{
Risk Perception of Bariatric Surgery in Patients with Different Obesity-Related Comorbidities
}

\author{
Fabiana Brum Schakarowski ${ }^{1, *}$ \\ Orcid.org/0000-0003-0486-4909 \\ Alexandre Vontobel Padoin ${ }^{2}$ \\ Orcid.org/0000.0002.9754.4818 \\ Cláudio Corá Mottin ${ }^{2}$ \\ Orcid.org/0000-0002-1638-2248 \\ Elisa Kern de Castro ${ }^{1}$ \\ Orcid.org/0000-0002-1290-7561
}

\author{
${ }^{1}$ Universidade do Vale do Rio dos Sinos, São Leopoldo, RS, Brasil \\ ${ }^{2}$ Pontificia Universidade Católica do Rio Grande do Sul, Porto Alegre, RS, Brasil
}

\begin{abstract}
The preoperative stage of bariatric surgery requires that the patient be informed of the obesity-related comorbidities and the risks, benefits, and consequences of surgery. The study examined the preoperative risk perception of bariatric surgery in 128 patients with different comorbidities (heart disease, type 2 diabetes mellitus, hypertension, sleep apnea and dyslipidemia). Risk perception of surgery and associated comorbidities were evaluated using a risk perception questionnaire. Patients with diabetes mellitus type 2 , systemic hypertension, and sleep apnea were significantly more likely to perceive the risk of surgery compared to those with the other comorbidities. The results showed that educational interventions expand the risk perception of surgery, but independently of the perceived risk of the different comorbidities of obese patients. The study points to the possibility of identifying predictive factors of behavioral intention related to risk perception to improve short and long-term treatment outcomes in patients whose comorbidities are seen as posing no additional health risk.
\end{abstract}

Keywords: Risk perception, obesity, bariatric surgery.

\section{Percepção de Risco da Cirurgia Bariátrica em Pacientes com Diferentes Comorbidades Associadas à Obesidade}

\section{Resumo}

A etapa pré-operatória de cirúrgica bariátrica exige que paciente esteja informado sobre as comorbidades associadas à obesidade e dos riscos, benefícios e consequências da cirurgia. $\mathrm{O}$ estudo examinou a percepção de risco da cirurgia bariátrica em 128 pacientes, com diferentes comorbidades associadas (doenças cardíacas, diabetes mellitus tipo 2, hipertensão arterial, apneia do sono e dislipidemia) no pré-

* Mailing address: Universidade do Vale do Rio dos Sinos, Av. Unisinos, 950, Cristo Rei, São Leopoldo, RS, Brazil 93020-190. E-mail: fabwski@gmail.com, alexandre.padoin@pucrs.br, claudio.mottin@pucrs.br and elisakc@unisinos.br 
operatório de cirurgia bariátrica. A percepção de risco da cirurgia e das comorbidades associadas foram avaliadas através de um Questionário de Percepção de Risco. Os pacientes com diabetes mellitus tipo 2, hipertensão arterial e apneia do sono apresentaram avanço mais significativo, em relação as demais comorbidades, para a percepção de risco da cirurgia. Os resultados mostraram que as intervenções educativas expandem a percepção de risco da cirurgia, mas é independente o risco percebido entre as diferentes comorbidades dos pacientes obesos. $\mathrm{O}$ estudo aponta a possibilidade de identificar fatores preditivos do comportamento implícito relacionados com a percepção de risco para melhorar o resultado do tratamento a curto e longo prazo, nos pacientes cujas comorbidades são vistas como não oferecendo risco adicional à saúde.

Palavras-chave: Percepção de risco, obesidade, cirurgia bariátrica.

\section{La Percepción del Riesgo de la Cirugía Bariátrica en Pacientes con Distintas Comorbilidades Asociadas con la Obesidad}

\section{Resumen}

El preoperatorio de cirugía bariátrica requiere que el paciente sea informado de las comorbilidades asociadas a la obesidad y los riesgos, beneficios y consecuencias de la cirugía. El estudio examinó la percepción de riesgo de la cirugía bariátrica en 128 pacientes con diferentes comorbilidades (enfermedades del corazón, diabetes mellitus tipo 2, hipertensión arterial, apnea del sueño y dislipidemia) en el preoperatorio de la cirugía bariátrica. La percepción de riesgo de la cirugía y las comorbilidades asociadas se evaluó mediante un cuestionario de percepción del riesgo. Los pacientes con diabetes mellitus tipo 2, hipertensión arterial y apnea del sueño tenían avance más significativo, en comparación con otras comorbilidades, a la percepción de riesgo de la cirugía. Los resultados mostraron que las intervenciones educativas ampliar la percepción del riesgo de la cirugía, pero es independiente de la percepción de riesgo entre las diferentes comorbilidades de los pacientes obesos. El estudio apunta a la posibilidad de identificar factores predictivos de comportamiento implícita relacionada con la percepción de riesgo para mejorar el resultado del tratamiento a corto y largo plazo en pacientes cuya comorbilidades son vistos como no proporcionar riesgo para la salud adicional.

Palavras clave: Percepción del riesgo, obesidad, cirúgia bariátrica.

Bariatric surgery has been considered effective for significant weight loss, improved comorbidities, and increased longevity of obese patients (Brzozowska, Sainsbury, Eisman, Baldock, \& Center, 2013; Sjöström et al., 2004). However, it cannot be perceived only as a technical action, based on an ideal model of contemporary health (Holtorf, Rinde, Rupprecht, Alder, \& Brixner, 2012). From the beginning of treatment with bariatric surgery, patients must know the diagnosis of their illness (obesity) and judge the risks, benefits and consequences of the surgery (Adams et al., 2007; Alvarez, Singh, \& Sinha, 2014, Kubik, Gill, Laffin, \& Karmali, 2013).

It is known that clinical comorbidities are not always reversed when patients regain weight in the long term and when psychiatric disorders established since childhood precede bariatric surgery (Ribeiro, Santos, \& Loureiro, 2011). Therefore, it is important that the patient be made aware of the behavioral changes intrinsic to the surgical procedure, which are determinant for the long-term sustainable outcome of the treatment (Friedman, Applegate, \& Grant, 2007; Murguía et al., 2012). Unrealistic expectations about bariatric surgery and its risks may undermine patient's ability to make required lifestyle changes (Kubik et al., 2013; Murguía et al., 2012). Hence, bariatric surgery should be used to complement other forms of obesity treatment (Cohen, Schiavon, \& Torres, 2010; Flum et al., 2009). 
People tend to assess risk situations based largely on the likelihood of consequences of associated diseases (Shiloh, Wade, Roberts, Alford, \& Biesecker, 2013), which precipitate the complications that may occur during and after surgery (Schauer et al., 2013, Wee et al., 2013, Wrzesinski et al., 2015). However, risk is a subjective construct involving outcome consequences that may differ between individuals. According to Slovic, Finucane, Peters, \& MacGregor (2004), risk can only be measured within a context, acquiring meaning as opposed to other data that interfere with its construction. The authors acknowledge that risk and risk responses permeate individual's values and state that it is not the real risk that affects decisions, but rather the perception of risk.

Risk perception, in turn, can be measured in terms of the perceived severity of the disease, the occurrence of the risk itself, or the degree of concern and fear associated with it, requiring an individual's intellectual judgment about the disease and its risk factors (Sjöberg, 1998). Thus, in order to reach better treatment outcomes and positive lifestyle reorganization, it is necessary that patients receive all the guidelines prior to surgery, promoting risk assessment and engagement in preventive behaviors to promote their health (Kaly et al. 2008; Sjöström et al., 2007).

Little is known about this risk perception in obese patients, considering different associated comorbidities. Detecting different distortions in risk perception of surgery and associated comorbidities may help the multidisciplinary team establish coping strategies with patients whose comorbidities are seen as posing no additional risk to the course of the disease. In this context, the present study aims to examine preoperative risk perception of bariatric surgery in patients with different obesity-related comorbidities.

\section{Methods}

This is an analytical, observational, and correlational study conducted to examine the associations between the variables investigated.

\section{Participants}

The sample consisted of 128 patients who were candidates for gastric bypass surgery at a tertiary care center for treatment of obesity within a hospital in Porto Alegre, Brazil, between September 2014 and January 2015. Participants were over 18 years old, literate, and did not have any intellectual impairment or cognitive limitation.

\section{Tools}

Sociodemographic Questionnaire. An instrument specifically designed for this study to collect the following patients' data from medical records reviewed by medical team: sex, age, living with a partner or not, educational attainment, work status, body mass index (BMI), duration of obesity, waiting time for surgery, and history of comorbidities.

Risk Perception Questionnaire. An instrument based on the study by Prasad et al. (2014) and designed to assess risk perception of surgery and associated comorbidities (heart disease, type 2 diabetes mellitus, systemic hypertension, sleep apnea, and dyslipidemia). Using a 5-point Likert scale $(1=$ no risk, $2=$ low risk, $3=$ medium risk, 4 $=$ high risk $5=$ very high risk), participants rated their perceived risk of comorbidities by answering two questions: - "Before entering the treatment program, how much did you consider yourself at risk for obesity-related comorbidities?" - "Since you entered the treatment program, how much have you considered yourself at risk for obesity-related comorbidities?" Risk perception of the surgery was evaluated by asking patients how much they perceived the following items as a health risk: undergoing surgery, not undergoing surgery, and death due to surgical complications. The questionnaire was administered at the hospital's own outpatient clinic the day before surgery. There is still no validated tool to evaluate the perceived risk construct. Although the use of standardized scales increases the ability to reproduce results, the questionnaire used in the present study favored the evaluation of how different obesity-related comorbidities are associated with the risk perception of the surgery. 


\section{Data Collection Procedure}

After preoperative treatment with a multidisciplinary team and attending two mandatory educational lectures, all invited patients, who were about to undergo surgery, agreed to participate in the study and signed an informed consent form. The mandatory educational lectures are taught by specialists of the care center and was held in monthly meetings for each specialty. These lectures aimed to provide a realistic understanding of obesity and to emphasize, among other facts, that bariatric surgery favors the remission of obesity-related comorbidities, but, for the treatment to be effective, continuous self-regulation about the disease and inadequate habits is required, aiming to improve the quality of life. There is no limit to attending mandatory educational lectures, since patients are always encouraged to gain more personal control over their illness, regardless of the waiting time for the surgery, minimizing surgical risks and postoperative complications and improving treatment adherence.

\section{Data Analysis Procedure}

Quantitative data were expressed as mean and standard deviation or median and interquartile range in the violation of distributional assumptions. Categorical data were expressed as count and percentages. Univariate analysis was performed using a $t$ test or its non-parametric surrogate for quantitative variables and the chisquare test or Fisher's exact test for categorical data. Additionally, data related to risk perception of the surgery were evaluated in an ordinal logistic regression model, using patient sex as the main factor and adjusting for potential confounding effects (educational attainment, age $<45$ and $>45$, type 2 diabetes, and systemic hypertension). The level of significance was $5 \%$. Data were analyzed using the Statistical Package for the Sciences (SPSS), version 22.0 (SPSS Inc., Chicago, IL, USA).

\section{Ethical Procedures}

The study was approved by the Ethics Committees of the institutions involved. Other ethi- cal and technical precepts were recommended by Resolution 196/1996 of the National Health Council (Conselho Nacional de Saúde, CNS).

\section{Results}

The sample consisted of 128 patients, 93 women $(72.7 \%)$ and 35 men $(27.3 \%)$, with a mean age of 39.5 years $(S D=11.0)$. Most patients had a high school degree $(57.0 \%)$, followed by a bachelor's degree (31.2\%). Regarding marital status, $68.8 \%$ reported to be married. The mean waiting time for bariatric surgery was 10.44 months $(S D=7.7)$. The mean duration of obesity was 16.2 years $(S D=$ 7.9). The majority of the sample was employed (74.2\%). The mean body mass index (BMI) of the participants on the day before surgery was $47.00 \mathrm{~kg} / \mathrm{m} 2(S D=7.19)$. Regarding comorbidities, $3.1 \%$ of the patients had heart disease, $26.6 \%$ had type 2 diabetes mellitus, $63.3 \%$ had systemic hypertension, $31.3 \%$ had sleep apnea, and $66.4 \%$ had dyslipidemia. A detailed description of sociodemographic and clinical data is presented in Table 1.

In the univariate analysis, the perceived risk for heart disease was higher in men than in women when entering the treatment program $(\mathrm{OR}=$ $0.5,95 \% \mathrm{CI}=0.2-0.9, p=.047)$. Patients with higher BMI, the day before surgery, presented higher perceived risk scores for heart disease $(\mathrm{OR}=0.9,95 \% \mathrm{CI}=0.9-1.0, p=.029)$, type 2 diabetes $(\mathrm{OR}=0.9,95 \% \mathrm{CI}=0.9-1.0, p=.001)$ and death due to surgical complications $(\mathrm{OR}=$ $0.9,95 \% \mathrm{CI}=0.9-1.0, p=.001)$. In addition, the day before surgery, patients with heart disease were more likely to perceive the risks of undergoing surgery $(\mathrm{OR}=1.5,95 \% \mathrm{CI}=1.2-1.9, p$ $=.001)$ and not undergoing surgery $(\mathrm{OR}=1.6$, $95 \% \mathrm{CI}=1.2-2.1, p=.001)$. Patients with type 2 diabetes, the day before surgery, also had a higher risk scores for undergoing surgery $(\mathrm{OR}=$ $1.7,95 \% \mathrm{CI}=1.2-1.8, p=.001)$, not undergoing surgery $(\mathrm{OR}=1.7,95 \% \mathrm{CI}=1.3-2.3, p=.001)$, and death due to surgical complications $(\mathrm{OR}=$ $1.6,95 \% \mathrm{CI}=1.3-2.1, p=.001)$. For systemic hypertension $(\mathrm{OR}=1.6,95 \% \mathrm{CI}=1.2-2.2, p=$ .001 ) and dyslipidemia (OR 1.5, 95\% CI $=1.2$ - 
Table 1

Demographic and Clinical Characteristics of 128 Patients

\begin{tabular}{lccc}
\hline Characteristics & $\begin{array}{c}\text { Men } \\
(n=35)\end{array}$ & $\begin{array}{c}\text { Women } \\
(n=93)\end{array}$ & $P$ value \\
\hline Age (years) & & & .675 \\
$\quad<45$ & $25(71.4 \%)$ & $62(66.7 \%)$ & \\
$\quad>45$ & $10(28.6 \%)$ & $31(33.3 \%)$ & .398 \\
Living with a partner & $22(62.9 \%)$ & $66(71.0 \%)$ & \\
Educational attainment & & & \\
Elementary school & $5(14.3 \%)$ & $10(10.8 \%)$ & .110 \\
High school & $14(40.0 \%)$ & $59(63.4 \%)$ & \\
Bachelor's degree & $16(45.7 \%)$ & $24(25.8 \%)$ & .562 \\
BMI (kg/m²) & & & .023 \\
$\geq 35$ to $\leq 39.9$ & $1(2.9 \%)$ & $13(14.0 \%)$ & \\
$>40$ & $34(97.1 \%)$ & $80(86.0 \%)$ & .301 \\
Duration of obesity (years) & $16.9 \pm 9.1$ & $16.0 \pm 7.5$ & .264 \\
Waiting time for bariatric surgery (months) & $12.9 \pm 10.8$ & $9.5 \pm 5.9$ & .305 \\
History of comorbidities & & & .059 \\
Heart disease & $2(5.7 \%)$ & $2(2.2 \%)$ & \\
Type 2 diabetes & $12(34.3 \%)$ & $22(23.7 \%)$ & $56(60.2 \%)$ \\
Systemic hypertension & $25(71.4 \%)$ & $27(29.0 \%)$ & \\
Sleep apnea & $13(37.1 \%)$ & $57(61.3 \%)$ & \\
Dyslipidemia & $28(80.0 \%)$ & & \\
\hline
\end{tabular}

Note. $\mathrm{BMI}=$ body mass index.

2.0, $p=.001)$ the patients had higher perceived risk scores for death due surgical complications. Patients with sleep apnea (OR 1.6, 95\% CI = $1.2-2.0, p=.001$ ) also had higher perceived risk scores for not undergoing surgery.

The adjusted results of ordinal logistic regression analysis revealed that risk perceptions of surgery, undergoing surgery, not undergoing the surgery, and death due to surgical complications were very similar between the sexes. After adjustment by multivariate analysis, men presented a $60 \%$ higher perception of risk of death due to surgical complications than women. The analysis data are shown in Table 2. No significant differences were observed in the remaining multivariate analysis.

\section{Discussion}

The results show that there is variation in the perceived risk of surgery and associated comorbidities after multidisciplinary care and educational lectures required to undergo bariatric surgery. Men were found to seek treatment for obesity with comorbidities associated with more advanced stages of the disease, being more likely to perceive the risk of heart disease and death due to surgical complications than women. These results are consistent with data reported in previous studies, highlighting that men are less likely to be metabolically healthy when they undergo surgery (Chang et al., 2014; Lee et al., 2015). Women, in turn, seek bariatric surgery as 
Table 2

Crude Odds Ratio and Adjusted Odds Ratio for Patient Sex

\begin{tabular}{lcccccc}
\hline & \multicolumn{3}{c}{ Crude OR } & \multicolumn{3}{c}{ Adjusted OR } \\
\cline { 2 - 7 } & OR* & $95 \%$ CI & $P$ value & OR & $95 \%$ CI & $P$ value \\
\hline Surgical risk & 1.3 & $0.6-2.9$ & .512 & 1.3 & $0.6-3.0$ & .540 \\
Risk of undergoing surgery & 0.8 & $0.4-1.6$ & .593 & 0.9 & $0.4-1.9$ & .853 \\
Not undergoing surgery & 0.6 & $0.3-1.2$ & .137 & 0.5 & $0.2-1.3$ & .189 \\
Death due to surgical complications & 1.7 & $0.7-4.0$ & .202 & 1.6 & $0.7-3.8$ & .255 \\
\hline
\end{tabular}

Note. $\mathrm{OR}=$ odds ratio

a treatment modality with comorbidities associated with less advanced stages of the disease, possibly, because they are more concerned with social and aesthetic standards (Pona, Heinberg, Lavery, Ben-Porath, \& Rish, 2016; Steffen et al., 2012), although these aspects are not indication for surgery.

In the present study, patients with type 2 diabetes showed a significant increase in the perceived risk of not undergoing surgery, between the before entering the treatment program and the day before surgery. This increased risk perception among patients with type 2 diabetes may be explained by the fact that this disease often begins silently and, after educational lectures, patients appear to broaden their understanding of the threatening consequences of this serious illness, which may lead to amputation, renal failure, and vision loss. Other studies emphasize the importance of educational interventions to promote the understanding of illnesses ((Bonsaksen, Lerdal, \& Fagermoen, 2015; Breland, Fox, Horowitz, \& Leventhal, 2012; Jumean et al., 2012) so that patients, when perceiving themselves at greater risk, can develop greater personal control and modify their behavior. This reveals that, by realizing the further consequences of obesity itself, patients can fight the intensity and duration of obesity-related comorbidities to mitigate the risks of surgery.

Our results also show that patients with systemic hypertension, type 2 diabetes, and sleep apnea, after receiving detailed information about the risks and benefits of surgery, were significantly more likely to perceive the risks of surgery. In contrast, the day before surgery, in patients with dyslipidemia, there was a decrease in the perceived risk of undergoing surgery. This provides evidence for understanding that the perceived risk/benefit of bariatric surgery may support decision making in practice, based on the fact that the risk of dying due to associated comorbidities may be greater than the risk of undergoing surgery. Similar results were observed by Prasad et al. (2014), who concluded that patients undergoing bariatric surgery were more likely to perceive obesity as a greater risk to their health than the surgery itself. Conversely, patients who are managed medically generally underestimate cardiovascular risk in the long term and overestimate the surgical risk. It is necessary that patients perceive themselves as active agents in this process, with predictive perception of risk associated with bariatric surgery and obesity-related comorbidities, seeking motivation to adhere to treatment for the short- and long-term success of the intervention.

The present study has some limitations. Patients were about to be operated on and had already received detailed information from the multidisciplinary team about all the risks and benefits involved in the surgery.

It is possible that thinking of surgery as a major gain, with expectation of "cure" for obesity and accelerated weight loss, may attenuate the concern with comorbidities that are considered, perhaps, less insidious. Our findings confirm the complexity of the obesity and the importance of the psychological aspects involved, both for the worsening of the condition and for obtaining 
and maintaining lasting treatment results. Thus, it is suggested that future research investigate aspects involved in the identification of predictive factors of behavioral intention related to risk perception. In addition, our risk perception questionnaire can be improved and administered at different times, e.g. before the first clinical evaluation, immediately after surgery, and months after surgery.

\section{Conclusions}

In the clinical management of obese patients, the risk perception of bariatric surgery and obesity-related comorbidities changes after educational lectures. Educational interventions expand the risk perception of surgery, but independently of the perceived risk of the different comorbidities of obese patients. It should be emphasized that dyslipidemia is an important risk factor for obesity, and its understanding involves behavioral change.

It is hoped that this study will contribute to increase knowledge about the perceived risk construct in obesity, providing the basis for the qualification of multidisciplinary therapeutic approaches.

\section{References}

Adams, T. D., Gress, R. E., Smith, S. C., Halverson, R. C., Simper, S. C., Rosamond, W. D., ...Hunt, S. C. (2007). Long-term mortality after gastric bypass surgery. New England Journal of Medicine, 357(8), 753-761. doi:10.1056/NEJMoa066603

Alvarez, A., Singh, P. M., \& Sinha, A. C. (2014). Postoperative analgesia in morbid obesity. Obesity Surgery, 24(4), 652-659. doi:10.1007/ s11695-014-1185-2

Bonsaksen, T., Lerdal, A., \& Fagermoen, M. S. (2015). Trajectories of illness perceptions in persons with chronic illness: An explorative longitudinal study. Journal of Health Psychology, 20(7), 942-953. doi:10.1177/1359105313504235

Breland, J. Y., Fox, A. M., Horowitz, C. R., \& Leventhal, H. (2012). Applying a common-sense approach to fighting obesity. Journal of Obesity, 2012, 710427. doi:10.1155/2012/710427
Brzozowska, M. M., Sainsbury, A., Eisman, J. A., Baldock, P. A., \& Center, J. R. (2013). Bariatric surgery, bone loss, obesity and possible mechanisms. Obesity Reviews, 14(1), 52-67. doi:10.1111/j.1467-789X.2012.01050.x

Chang, Y., Kim, B. K., Yun, K. E., Cho, J., Zhang, Y., Rampal, S., ...Ryu, S. (2014). Metabolically-healthy obesity and coronary artery calcification. Journal of the American College of Cardiology, 63(24), 2679-2686. doi:10.1016/j. jacc.2014.03.042

Cohen, R., Schiavon, C. A., \& Torres, M. C. (2010). Cirurgia metabólica: Mudanças na anatomia gastrointestinal e a remissão do diabetes mellitus tipo 2. ABCD. Arquivos Brasileiros de Cirurgia Digestiva, 23(1), 40-45. doi:http://dx.doi. org/10.1590/S0102-67202010000100010

Flum, D. R, Belle, S. H., Berk, P., Chapman, W., Courcoulas, A., King, W. C., ...Yanovski, S. Z. (2009). Perioperative safety in the longitudinal assessment of bariatric surgery. New England Journal of Medicine, 361(5), 445-454. doi:10.1056/NEJMoa0901836

Friedman, K. E., Applegate, K. L., \& Grant, J. (2007). Who is adherent with preoperative psychological treatment recommendations among weight loss surgery candidates? Surgery for Obesity and Related Diseases, 3(3), 376-382. doi:http:// dx.doi.org/10.1016/j.soard.2007.01.008

Holtorf, A. P., Rinde, H., Rupprecht, F., Alder, H., $\&$ Brixner, D. (2012). The economic impact of bariatric surgery. Advanced Bariatric and Metabolic Surgery. doi:10.5772/33003

Jumean, M. F., Korenfeld, Y., Somers, V. K., Vickers, K. S., Thomas, R. J., \& Lopez-Jimenez, F. (2012). Impact of diagnosing metabolic syndrome on risk perception. American Journal of Health Behavior, 36(4), 522-532. doi:10.5993/ AJHB.36.4.9

Kaly, P., Orellana, S., Torrella, T., Takagishi, C., SaffKoche, L., \& Murr, M. M. (2008). Unrealistic weight loss expectations in candidates for bariatric surgery. Surgery for Obesity and Related Diseases, 4(1), 6-10. doi:10.1016/j. soard.2007.10.012

Kubik, J. F., Gill, R. S., Laffin, M., \& Karmali, S. (2013). The impact of bariatric surgery on psychological health. Journal of Obesity, 2013, 837989. doi:10.1155/2013/837989

Lee, C. J., Clark, J. M., Asamoah, V., Schweitzer, M., Magnuson, T., \& Lazo, M. (2015). Preva- 
lence and characteristics of individuals without diabetes and hypertension who underwent bariatric surgery: Lessons learned about metabolically healthy obese. Surgery for Obesity and Related Diseases, 11, 142-147. doi:10.1016/j. soard.2014.06.012

Murguía, M. S., Sierra, A. V., Barragán, V. R, Hernandéz, J. C. L., Rodriguéz, M. E. R., \& Tamayo, M. T. (2012). Psychosocial profile of bariatric surgery candidates and the correlation between obesity level and psychological variables. International Journal of Psychology \& Psychological Therapy, 12(3), 405-414.

Pona, A. A., Heinberg, L. J., Lavery, M., Ben-Porath, Y. S., \& Rish, J. M. (2016). Psychological predictors of body image concerns 3 months after bariatric surgery. Surgery for Obesity and Related Diseases, 12(1), 188-193. doi:10.1016/j. soard.2015.05.008

Prasad, C., Batsis, J. A., Lopez-Jimenez, F., Clark, M. M., Somers, V. K., Sarr, M. G., \& CollazoClavell, M. L. (2014). Risk perception of obesity and bariatric surgery in patients seeking treatment for obesity. European Journal of Preventive Cardiology, 21(6), 692-703. doi:10.1177/2047487312466904

Ribeiro, G. A. N. de A., Santos, J. E. dos, \& Loureiro, S. R. (2011). Perfil psicológico de mulheres e a cirurgia bariátrica: Estudo exploratório. Revista Interamericana de Psicologia, 2(45), 169-176.

Schauer, D. P., Arterburn, D. E., Wise, R., Boone, W., Fischer, D., \& Eckman, M. H. (2013). Predictors of bariatric surgery among an interested population. Surgery for Obesity and Related Diseases. doi:10.1016/j.soard.2013.09.014

Shiloh, S., Wade, C. H., Roberts, J. S., Alford, S. H., \& Biesecker, B. B. (2013). Associations between risk perceptions and worry about common diseases: A between- and within-subjects examination. Psychology \& Health, 28(4), 434-449. doi:10.1080/08870446.2012.737464

Sjöberg, L. (1998). Worry and risk perception. Risk Analysis, 18(1), 85-93. oi:10.1111/ j.15396924.1998.tb00918.x
Sjöström, L., Lindroos, A. K., Peltonen, M., Torgerson, J., Bouchard, C., Carlsson, B., ...Swedish Obese Subjects Study Scientific Group. (2004). Lifestyle, diabetes, and cardiovascular risk factors 10 years after bariatric surgery. New England Journal of Medicine, 351(26), 2683-2693. doi:10.1056/NEJMoa035622

Sjöström, L., Narbro, K., Sjöström, C. D., Karason, K., Larsson, B., Wedel, H., ...Swedish Obese Subjects Study. (2007). Effects of bariatric surgery on mortality in Swedish obese subjects. New England Journal of Medicine, 357(8), 741752. doi:10.1056/NEJMoa066254

Slovic, P., Finucane, M. L., Peters, E., \& MacGregor, D. G. (2004). Risk as analysis and risk as feelings: Some thoughts about affect, reason, risk, and rationality. Risk Analysis, 24(2), 311322. doi:10.1111/j.0272-4332.2004.00433.x

Steffen, K. J., Sarwer, D. B., Thompson, J. K., Mueller, A., Baker, A. W., \& Mitchell, J. E. (2012). Predictors of satisfaction with excess skin and desire for body contouring after bariatric surgery. Surgery for Obesity and Related Diseases, 8(1), 92-97. doi:10.1016/j.soard.2011.06.022

Wee, C. C., Hamel, M. B., Apovian, C. M., Blackburn, G. L., Bolcic-Jankovic, D., Colten, M. E., ...Jones, D. B. (2013). Expectations for weight loss and willingness to accept risk among patients seeking weight loss surgery. JAMA Surgery, 148(3), 264-271. doi:10.1001/ jamasurg.2013.1048

Wrzesinski, A., Corrêa, J. M., Fernandes, T. M. B., Monteiro, L. F., Trevisol, F. S., \& Nascimento, R. R. (2015). Complications requiring hospital management after bariatric surgery. $A B C D$. Arquivos Brasileiros de Cirurgia Digestiva, 28(Supl. 1), 3-6 doi:http://dx.doi.org/10.1590/ S0102-6720201500S100003

Recebido: 02/10/2016

$1^{\text {st }}$ revision: $30 / 12 / 2016$

$2^{\text {nd }}$ revision: $15 / 02 / 2017$

Accepted: 16/02/2017

(C) The Author(s), 2018. Open Access. This article is distributed under the terms of the Creative Commons Attribution 4.0 International License (http://creativecommons.org/licenses/by/4.0/), which permits unrestricted use, distribution, and reproduction in any medium, provided you give appropriate credit to the original author(s) and the source, provide a link to the Creative Commons license, and indicate if changes were made. 